УДК 159.9.072.5:159.923.2

https://doi.org/10.52058/2708-7530-2022-1(19)-413-424

Данильченко Тетяна Вікторівна доктор психологічних наук, доцент, професор кафедри психології, Академія Державної пенітенціарної служби, м. Чернігів, 14000, вул. Гонча, 34, тел.: (067)525-17-47, https://orcid.org/0000-0001-8809-0132

\title{
ПСИХОМЕТРИЧНІ ХАРАКТЕРИСТИКИ ШКАЛИ ПСИХОЛОГІЧНОГО БЛАГОПОЛУЧЧЯ Л.В. ЖУКОВСЬКОЇ, Є.Г. ТРОШИХІНОї
}

Анотація. В статті описується процедура та результат психометричної перевірки Шкали психологічного благополуччя в адаптації Л.В. Жуковської, Є.Г. Трошихіної. Теоретичною основою $є$ уявлення про психологічне благополуччя К. Ріфф. Останнє розглядається за К. Ріфф як конструкт, що відображає сприймання й оцінку свого функціонування з точки зору вершини потенційних можливостей. Вибірку дослідження склали громадяни України 3 різних регіонів - 41,9\% чоловіків, 58,1\% жінок від 20 до 64 років (N=903). Середній вік - 30,5 років.

За всіма параметрами Шкали психологічного благополуччя виявлені статистично достовірні відмінності від нормального розподілу. Конструктна валідність перевірялася за допомогою факторного аналізу, однак шести факторна модель виявилася непридатною. Перший фактор був суттєво вагоміший за інші. Він об'єднав характеристики, що відображали параметри неблагополуччя: невдачі, нездатність керувати своїм життям, підкореність обставинам. Зображення стосунків мало негативний характер. Найменш актуалізованим фактором виявилось самоприйняття.

Надійність шкал методики прийнятна - $\alpha$ Кронбаха від 0,688 до 0,791. Сумнівна надійність шкали самоприйняття може бути підвищена до 0,774 при вилученні одного питання. Загальний показник надійності методики $-0,845$ (гарна внутрішня узгодженість). Значущість кореляційних зв'язків між окремими шкалами підтвердила доцільність їх об’єднання в єдиний конструкт. Зовнішня валідність методики підтверджена.

Все вище перераховане дає можливість зробити висновок, що варіант Шкали психологічного благополуччя Л.В. Жуковської, Є.Г. Трошихіної потрібно застосовувати у вітчизняній психодіагностичній $\mathrm{i}$ науководослідницькій практиці з обережністю.

Ключові слова: психологічне благополуччя, самоприйняття, автономія, компетентність, особистісне зростання, валідність, шкала 
Danylchenko Tetiana Victorivna Doctor of psychological sciences, assistant professor, professor of the department of psychology, Academy of the State Penitentiary Service, Goncha St., 34, Chernihiv, 14000, tel.: (067) 525-17-47, https://orcid.org/0000-0001-8809-0132

\title{
PSYCHOMETRIC CHARACTERISTICS OF THE SCALE OF PSYCHOLOGICAL WELL-BEING L.V. ZHUKOVSKA, E.G. TROSHIKHINA
}

\begin{abstract}
The article describes the procedure and the result of psychometric testing of the Ryff Scales of psychological Well-being in the adaptation of L.V. Zhukovskaya, E.G. Troshikhina. The theoretical basis is the idea of psychological well-being K. Riff. The latter is considered by K. Riff as a construct that reflects the perception and evaluation of its functioning in terms of the peak of potential. The sample consisted of citizens of Ukraine from different regions $-41.9 \%$ of men, $58.1 \%$ of women aged 20 to $64(\mathrm{~N}=903)$. The average age is 30.5 years.

Statistically significant differences from the normal distribution were found for all parameters of the Ryff Scales of psychological Well-being. Constructive validity was verified by factor analysis, but the six-factor model proved unsuitable. The first factor was significantly more important than the others. He combined characteristics that reflected the parameters of adversity: failure, inability to control their lives, submission to circumstances. The image of the relationship was negative. The least relevant factor was self-acceptance.
\end{abstract}

The reliability of the scales of the method is acceptable - Cronbach's $\alpha$ from 0.688 to 0.791 . Doubtful reliability of the self-acceptance scale can be increased to 0.774 by removing one question. The overall reliability of the method is 0.845 (good internal consistency). The importance of correlations between individual scales confirmed the expediency of combining them into a single construct. The external validity of the method is confirmed.

All of the above allows us to conclude that the version of the Ryff Scales of psychological Well-being L.V. Zhukovskaya, E.G. Troshikhina should be used in domestic psychodiagnostic and research practice with caution.

Keywords: psychological well-being, self-acceptance, autonomy, competence, personal growth, validity, scale

Постановка проблеми. Психологічне благополуччя особистості стало центральною проблемою психології останніх десятиліть. Перехід фокусу досліджень від вивчення «людини, що страждає» до «людини, що насолоджується життям» стало причиною появи нового напрямку - позитивної психології. Фокус суспільних очікувань змінився і в політиці, що знайшло відображення в появі цілої низки різноманітних індексів, за допомогою яких країни порівнюють своїх громадян за рівнем переживання благополуччя / 
щастя. Індекси здебільшого використовуються в соціологічних дослідженнях. Постала проблема побудови адекватного інструментарію для вивчення оптимального функціонування особистості. Найбільш поширеними методиками вивчення суб'єктивного (гедоністичного) благополуччя стала Шкала задоволеності життям Е. Дінера (Satisfaction with Life Scale, 1985), a психологічного (евдемонічного) благополуччя - Шкала психологічного благополуччя К. Ріфф (Ryff Scales of psychological Well-being, 1989). Однак шкали, які описують критерії ідеального життя, невідворотно будуть мати культурну специфіку, зумовлену географічними, історичними та економічними умовами. Тому питання адаптації методик до культурного контексту є важливим завданням як для психологічної практики, так і для науково-дослідницької роботи.

Аналіз останніх досліджень і публікацій. He зупиняючись на методологічних дискусіях щодо визначення феноменів оптимального функціонування особи, звернемось до психологічного (евдемонічного) благополуччя, яке визначається як базовий суб'єктивний конструкт, що відображає сприймання й оцінку свого функціонування 3 точки зору вершини потенційних можливостей [1]. Психологічне благополуччя відображає потенціал людини вести значуще життя i справлятися 3 повсякденними проблемами, це «оцінюваний людиною рівень власної компетентності та свого Я, співвіднесений з особистою ієрархією цілей» [2, с. 328].

Найбільш відома концепція психологічного благополуччя К. Ріфф, яка виділила такі його компоненти як особистісне зростання, автономія, самоприйняття, гарні стосунки, компетентність і цілі в житті. Авторкою був запропонований інструмент для виміру психологічного благополуччя. Методика була опублікована в 1989 році і переведена на більш ніж як 25 мов [3], зокрема російську та українську (адаптація С.В. Карсканової, 2011) [4].

Зазначимо, що українська версія методики К. Ріфф порівняно мало поширена у вітчизняній психологічній спільноті [5; 6; 7]. Більш часто використовують адаптацію Т.Д. Шевеленкової і П.П. Фесенко, 2005 [8; 9; 10; 11; 12; 13]. Рідше зустрічаємо адаптацію Н.Н. Лепешинського, 2007 [14]. Версія Л.В. Жуковської і Є.Г. Трошихіної (2011) майже не зустрічається [15].

На нашу думку, варіант Л.В. Жуковської і Є.Г. Трошихіної має одну перевагу для масових досліджень - вона суттєво коротша. Якщо всі вище зазначені адаптації співпадають з оригіналом і мають 84 запитання, то у цій версії їх 54. Тому для подальшої роботи була використана саме версія Л.В. Жуковської і Є.Г. Трошихіної.

Очевидно, що феномен благополуччя суттєво залежить від культурних умов, в яких відбувається соціалізація особистості. Уявлення про ідеальний стан (життя) мають ціннісне забарвлення, тому адаптація методик до умов певної культури є досить складним завданням.

Саме тому мета статті - перевірити психометричні характеристики 
шкали психологічного благополуччя в адаптації Л. В. Жуковської, Є. Г. Трошихіної для українських респондентів.

Методи дослідження. В дослідженні були використані наступні методи: Шкала психологічного благополуччя (ШПБ) К. Ріфф в адаптації Л. В. Жуковської, Є. Г. Трошихіної; для дослідження зовнішньої валідності були використані Шкала задоволеності життям Е. Дінера (в адаптації Д.О. Леонтьєва та Є.М. Осіна, 2008) [16]; Шкала суб'єктивного соціального благополуччя (для аналізу шкали Позитивні стосунки) [17]; СЖО Д.О. Леонтьєва (шкала Цілі в житті); Опитувальник цінностей Ш. Шварца (в адаптації В.Н. Карандашева, 2004) (шкала Автономія); Тест впевненості в собі В.Г. Ромека (2008) (шкала Компетентність, Самоприйняття); Опитувальник життєстійкості С. Мадді (шкала Особистісне зростання).

В дослідженні, яке проводилось протягом 2016-2021 pp. в різних регіонах України, взяло участь 903 особи, з них 525 жінок і 378 чоловіків. Віковий діапазон від 20 до 64 років, середній вік - 30,55 $( \pm 11,33)$ років.

Статистична обробка даних здійснювалася за допомогою програми SPSS 17.0 та AMOS 15.0. Використовувались експлораторний та конфірматорний факторний аналіз, кореляційний аналіз, розрахунок коефіцієнту надійності.

Виклад основного матеріалу. На першому етапі здійснювалася перевірка на нормальність за допомогою критерію Колмогорова-Смирнова. За всіма параметрами Шкали психологічного благополуччя виявлені статистично достовірні відмінності від нормального розподілу. Зазначимо, що у авторів адаптації методики нормального розподілу даних теж не було отримано. Якщо ми звернемося до критерію асиметрії-ексцесу (таблиця 1), то очевидно, що найбільші відхилення від нормального розподілу має автономія (частіше зустрічаються значення нижче середнього, що, на нашу думку, можна пояснити особливостями української культури) та самоприйняття (частіше зустрічаються значення вище середнього, що є психологічною нормою). Однак оскільки медіана і середні значенні відрізнялись несуттєво, а значення асиметрії та ексцесу не перевищують 1, в подальшому для розрахунку використовувались параметричні критерії.

Таблиця 1

Первинна описова статистика шкал ШПБ

\begin{tabular}{|l|l|l|l|l|l|l|}
\hline \multirow{2}{*}{ Шкала } & \multirow{2}{*}{ Ш } & \multirow{2}{*}{$\sigma$} & \multicolumn{2}{c|}{ Асиметрія } & \multicolumn{2}{c|}{ Ексцес } \\
\cline { 4 - 7 } & & & Знач. & Похиб. & Знач. & Похиб. \\
\hline Автономія & 28,78 & 5,166 & 0,368 & 0,086 & 0,082 & 0,172 \\
\hline Компетентність & 29,88 & 4,929 & 0,058 & 0,086 & 0,188 & 0,172 \\
\hline Особистісне зростання & 33,33 & 4,676 & 0,001 & 0,086 & $-0,110$ & 0,172 \\
\hline Позитивні стосунки & 32,85 & 5,631 & $-0,192$ & 0,086 & $-0,207$ & 0,172 \\
\hline Життєві цілі & 32,70 & 5,320 & $-0,063$ & 0,086 & 0,090 & 0,172 \\
\hline Самоприйняття & 31,22 & 5,185 & $-0,331$ & 0,086 & 0,320 & 0,172 \\
\hline Загальний показник ПБ & 188,81 & 23,241 & 0,116 & 0,086 & $-0,066$ & 0,172 \\
\hline
\end{tabular}


Конструктна валідність перевірялася за допомогою факторного аналізу (за методом максимальної правдоподібності з обертанням Varimax). Отримана структура порівнювалася із авторською. Адекватність використання факторного аналізу перевірялася за допомогою значущості коефіцієнта Кайзера - Майєра - Олкіна $(0,923)$, а також коефіцієнта Бартлетта $(14078,78$ при $\mathrm{p} \leq 0,01)$.

На першому етапі було виділено шість факторів, які пояснили лише 40,28\% загальної дисперсії, що в цілому співпадає з авторською версією. При цьому перший фактор був суттєво більше навантаженим порівняно $з$ іншими (внесок в загальну дисперсію - 20,06\%). Ми позначили цей фактор як «Безпорадність». В нього увійшли такі питання: «Я схильний піддаватися впливу людей з твердими переконаннями» (факторне навантаження $-0,611$, автономія), «Мені здається, що багато з людей, яких я знаю, одержали від життя більше, ніж я» $(0,585$, самоприйняття), «Я не маю чіткого усвідомлення того, чого я намагаюся досягти в житті» $(0,580$, цілі), «Труднощі повсякденного життя часто нервують мене» $(0,573$, компетентність), «Я часто відчуваю, що я недостатньо здібний» $(0,549$, компетентність), «Я часто думаю, що живу неправильно» (0,534, самоприйняття), «Я дуже давно перестав намагатися поліпшити або змінити що-небудь в своєму житті» $(0,513$, особистісне зростання), «Я часто змінюю свої рішення, якщо оточуючі не згодні $з$ ними» $(0,505$, автономія), «Мені складно організувати своє життя так, щоб мене це влаштовувало» $(0,492$, компетентність), «Іноді я змінюю свою поведінку, щоб не виділятися» $(0,474$, автономія), «Раніше я ставив перед собою цілі, але зараз це здається марною тратою часу» $(0,467$, цілі), «Я багато в чому розчарований своїми досягненнями в житті» $(0,442$, самоприйняття), «Я живу одним днем і не замислююся серйозно щодо майбутнього» $(0,409$, цілі). Таким чином, бачимо включеність в цей фактор тверджень 3 усіх шкал (за виключенням позитивних стосунків), які відображають негативний полюс: невдачі, нездатність керувати своїм життям, підкореність обставинам. В цілому, це образ людини, що має депресивні переживання. На нашу думку, важливо з'ясувати, чи є вказане явище артефактом переживання сучасників, чи ми зіткнулися з неадекватністю застосування самої методики.

Другий фактор (5,85\%) об'єднав питання, що переважно стосуються опису позитивних стосунків: «Я часто відчуваю себе самотнім через те, що у мене мало близьких друзів» $(0,623)$, «Я отримую теплоту і підтримку від друзів і близьких» $(-0,601)$, «Мені завжди не вистачало теплих і довірливих стосунків з іншими» $(0,601)$, «Мені завжди було складно і виснажливо підтримувати близькі стосунки 3 людьми» $(0,575)$, «Я знаю, що можу довіряти своїм друзям, а вони теж можуть довіряти мені» $(-0,562)$, «Я часто відчуваю, що залишаюся осторонь, коли справа стосується дружби» $(0,562)$, «Я знаю небагато людей, охочих вислухати, коли мені потрібно з кимсь поговорити» $(0,538)$, «Мені не вистачає здібностей, щоб успішно ладити з людьми» $(0,413)$, «Я відчуваю задоволення від особистого і взаємного спілкування з членами 


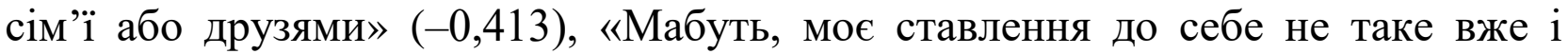
гарне» $(0,400)$. При чому, як і в попередньому випадку, привертає увагу негативний характер зображення стосунків: домінуючим є негативний полюс взаємин. Тому більш адекватною назвою фактору, на нашу думку, буде «Негативні стосунки».

Третій фактор (4,38\%) увібрав всі дескриптори шкали особистісного зростання: «Коли я міркую про майбутнє, я відчуваю наснагу і бажання діяти» (0,532), «В своєму житті я вважаю важливим все більше і більше дізнаватися про себе» $(0,528)$, «Для мене життя - це постійний процес навчання, змін, зростання» (0,511), «Мене приваблюють справи, які можуть розширити поле моїх можливостей» $(0,503)$, «Я не хочу що-небудь робити по-новому, в моєму житті мене все влаштовує таким, як воно є» $(-0,500)$, «Мені приносить задоволення будувати плани на майбутнє i працювати над їх втіленням в життя» $(0,489)$, «Я вважаю, що важливо переживати новий досвід, який змінює звичні уявлення» $(0,482)$, «Я вважаю, що людина може розвиватися i в похилому віці» $(0,440)$, «Деякі люди безцільно блукають життям, але я не один 3 них» $(0,410)$. Структура цього фактору повністю відповідає авторській моделі.

Четвертий фактор (4,26\%) здебільшого об’єднав характеристики компетентності: «Я досить добре справляюся 3 щоденними обов'язками» $(0,589)$, «Я вмію гарно розподіляти час, а тому встигаю зробити все, що мені необхідно» $(0,545)$, «Я здатен грамотно розпоряджатися своїми грошима» $(0,529)$, «Зазвичай я гарно ставлюсь до себе і довіряю собі» $(0,457)$, «Мої щоденні справи здаються мені банальними і незначними» $(-0,415)$.

П'ятий фактор (3,24\%) утворений такими дескрипторами: «Я оцінюю себе за тим, що я вважаю важливим, а не за критеріями, які вважають важливими оточуючі» $(0,602)$, «Я впевнений в своїх поглядах, навіть якщо це не відповідає загальноприйнятій думці» $(0,530)$, «Для мене важливіше бути в ладу з самим собою, ніж погоджуватися з іншими людьми» $(0,519)$, «На моє рішення зазвичай не впливає те, яким чином в таких випадках діють інші» $(0,508)$, «Я не боюся висловлювати вголос те, що я думаю, навіть якщо це не відповідає думці оточуючих» $(0,450)$, «Мені дуже важливо знати, як мої вчинки оцінюють інші люди» $(-0,431)$, це дало можливість позначити цей фактор як «Автономія».

Останній фактор (2,48\%) утворений лише трьома характеристиками: «Коли я проглядаю історію свого життя, я задоволений тим, як все склалося» $(0,650)$, «Я зміг налаштувати своє життя на свій смак» $(0,596)$, «У минулому були зльоти і падіння, але в цілому я б не став нічого міняти» $(0,519)$, i відображає параметри самоприйняття.

Після обертання не була досягнута проста структура. Три питання («В цілому мені подобається мій характер», «Незважаючи на свої недоліки, я приймаю себе таким, яким я є», «Мені здається, що я не змінився за прожиті роки») мали факторне навантаження менше 0,35. Перевірка цієї моделі 
засобами конфірматорного факторного аналізу також підтвердила, що вона має низький рівень узгодженості (RMSEA=0,082, CFI=0,897, GFI=0,821), відповідно авторська модель не відповідає емпіричним даним, отриманих в нашому дослідженні.

Дискримінантна валідність перевірялась шляхом підрахунку коефіцієнтів кореляції для окремих шкал опитувальника. Вони виявились в межах від 0,311 до 0,664 (таблиця 2). Зазначимо, що психологічне благополуччя - надзвичайно синергетичний феномен, тому зазвичай його показники складно відділити один від одного. Тому показники кореляції між шкалами доволі високі, оскільки вони відображають єдиний системний феномен. Найслабший зв'язок виявлений між шкалами автономії і позитивних стосунків.

В теорії самодетермінації Е. Десі та Р.М. Райяна автономія розглядається як прагнення відчувати вибір і детермінацію власної поведінки незалежно від впливу зовнішнього оточення та внутрішньо-особистісних процесів [18]. Відчуття себе автономним суб'єктом не означає індивідуалізму, або повної незалежності від інших людей, мається на увазі, що дії стають свідомо обраними суб'єктом. На думку американських дослідників М. Деміра та колег, автономія є не критерієм (складовою), а механізмом благополуччя, оскільки слугує фільтром для психологічних наслідків позитивних емоцій, викликаних включеністю в соціальне середовище [19]. Таким чином, кореляційні зв'язки автономії з позитивними стосунками є закономірними. Зазначимо, що в умовах української культури продовжує цінуватися слухняність, а тому самостійність, незалежність у прийнятті рішень може трактуватися як бажання не дослухатися до думки інших i викликати негативні реакції з боку оточуючих.

Найтісніший зв'язок виявлено між компетентністю і самоприйняттям. Сприймання здатності влаштувати життя на власний смак як досягнення виникло порівняно недавно, в зв'язку з поширенням європейських цінностей, однак, як бачимо, вже стало критерієм оцінки власної особистості. Найслабші (автономія - позитивні стосунки) i найтісніші (самоприйняття компетентність) зв’язки були виявлені і авторами модифікації методики, що дає можливість припустити певну тенденцію.

Таблицяя 2

Матриця кореляцій між шкалами ШПБ*

\begin{tabular}{|l|l|l|l|l|l|l|}
\hline \multicolumn{1}{|c|}{ Шкала } & Автоном. & Компет. & Ос. зрос. & Поз. ст. & Ж. цілі & Самопр. \\
\hline Автономія & & 0,430 & 0,441 & 0,311 & 0,354 & 0,394 \\
\hline Компетентність & & & 0,409 & 0,522 & 0,592 & 0,664 \\
\hline Особистісне зростання & & & & 0,473 & 0,538 & 0,399 \\
\hline Позитивні стосунки & & & & & 0,485 & 0,565 \\
\hline Життєві цілі & & & & & & 0,589 \\
\hline Самоприйняття & & & & & & \\
\hline Загальний показник ПБ & 0,647 & 0,800 & 0,713 & 0,755 & 0,793 & 0,803 \\
\hline
\end{tabular}

* всі кореляції мають рівень статистичної значущості 0,01 
Зазначимо, що внесок кожної шкали в оцінку загального рівня психологічного благополуччя неоднаковий: найбільш вагомою виявилася шкала самоприйняття (яке, на думку К. Хорні, взагалі є базовим переживанням здорової особистості), а порівняно менш значущою стала шкала автономії. Стосовно цього параметру як складової психологічного благополуччя до сьогодні тривають дискусії. Так, Ф. Хьюперт в своїх емпіричних дослідженнях не знайшла підтвердження, що автономія необхідна для процвітання (протилежного полюсу депресії) [20]. Вона пояснює, що автономія зумовлена особливостями індивідуалістичної чи колективістської культури. Мало того, автономія може сприяти зниженню благополуччя, оскільки підштовхує людей до думки, що вони нічого не варті, їх ніхто не помічає, вони не відіграють важливої ролі в житті інших [21, с. 220].

3 загальним показником психологічного благополуччя в найбільшій мірі корелює самоприйняття, в найменшій - автономія (теж повторює тенденцію дослідження 2011 р.). В цілому, коефіцієнти кореляції окремих шкал 3 загальним показником достатньо високі, що свідчить про існування цілісного конструкту психологічного благополуччя.

Надійність методики перевірялась за допомогою коефіцієнта $\alpha$ Кронбаха, який був розрахований для окремих шкал та для опитувальника в цілому (таблиця 3). В таблиці наводиться порівняння з оригінальними даними авторів модифікації. Всі отримані коефіцієнти достатньо високі, що свідчить про внутрішню узгодженість шкал.

Отримані значення коефіцієнту надійності шкал $\epsilon$ прийнятними. Коефіцієнт надійності для всіх 54 питань шкали, скомбінованих в єдину узагальнену шкалу теж виявився гарним - 0,845 (більше 0,8). Сумнівною $\epsilon$ надійність шкали самоприйняття. Виявлено одне питання («Незважаючи на свої недоліки, я приймаю себе таким, яким я є»), при виключенні якого 3 шкали самоприйняття альфа Кронбаха зростає до 0,774.

Таблиия 3

Показники надійності окремих шкал та ШПБ в цілому

\begin{tabular}{|c|l|l|l|l|l|}
\hline Шкала & $\begin{array}{l}\text { Кіль- } \\
\text { кість } \\
\text { пунктів }\end{array}$ & $\begin{array}{l}\alpha \\
\text { Кронба- } \\
\text { ха }\end{array}$ & $\begin{array}{l}\text { Коефіцієнт } \\
\text { розщеплення }\end{array}$ & $\begin{array}{l}\text { Середній } \\
\text { коефіцієнт } \\
\text { кореляції між } \\
\text { пунктами }\end{array}$ & $\begin{array}{l}\alpha \text { Кронбаха в } \\
\text { адаптації } \\
\text { Л.В. Жуковської } \\
\text { i .Г. Трошихіної }\end{array}$ \\
\hline Автономія & 9 & 0,705 & 0,576 & 0,211 & 0,71 \\
\hline Компетентність & 9 & 0,691 & 0,500 & 0,202 & 0,72 \\
\hline $\begin{array}{c}\text { Особистісне } \\
\text { зростання }\end{array}$ & 9 & 0,700 & 0,576 & 0,213 & 0,76 \\
\hline $\begin{array}{c}\text { Позитивні } \\
\text { стосунки }\end{array}$ & 9 & 0,791 & 0,618 & 0,444 & 0,79 \\
\hline Життєві цілі & 9 & 0,765 & 0,677 & 0,267 & 0,79 \\
\hline Самоприйнятя & 9 & 0,668 & 0,608 & 0,172 & 0,80 \\
\hline Загальний & 54 & 0,845 & 0,828 & 0,479 & 0,91 \\
\hline показник Пь & & & & & \\
\hline
\end{tabular}


Зовнішня валідність перевірялася за допомогою кореляційного аналізу показників окремих шкал ПШБ. Так, шкала Автономія має статистично достовірні зв'язки 3 показниками незалежності як цінності ( $\mathrm{r}=0,409$ при $\mathrm{p} \leq 0,01)$. Шкала Життєві цілі найбільш тісно пов'язана із шкалою Ціль СЖО $(\mathrm{r}=0,432$ при $\mathrm{p} \leq 0,01)$. Шкала Компетентність корелює із задоволеністю життям $(\mathrm{r}=0,419$ при $\mathrm{p} \leq 0,01)$ та соціальною помітністю $(\mathrm{r}=0,351$ при $\mathrm{p} \leq 0,01)$. Шкала Позитивні стосунки пов'язана з емоційним прийняттям ( $\mathrm{r}=0,521$ при $\mathrm{p} \leq 0,01)$. Шкала Самоприйняття має зв'язок із впевненістю $(\mathrm{r}=0,535$ при $\mathrm{p} \leq 0,01)$. Особистісне зростання корелює із прагненням до ризику ( $\mathrm{r}=0,511$ при $\mathrm{p} \leq 0,01$ ), прагненням до змін (інтегральний індекс 3 Опитувальника цінностей Ш. Шварца) (r=0,365 при $\mathrm{p} \leq 0,01)$.

Зауважимо, що в нашому дослідженні не проводилась перевірка ретестової надійності методики, оскільки ми виходили з припущення, що психологічне благополуччя може залежати від життєвих обставин конкретного індивіда, а тому суттєво варіювати, однак це не буде свідченням низької надійності шкали.

Другим зауваженням до цієї версії шкали є наявні тестові норми тільки для жіночої частини вибірки, оскільки автори адаптації вважали, що жінки частіше звертаються за психологічною допомогою, а тому така версія є більш актуальною. Тому цю адаптацію доцільно використовувати 3 дослідницькою метою, однак вона має обмеження для психологічної практики.

Третім, найбільш принциповим, зауваженням $є$ невідтворення авторської структури шкал - конструктна валідність в нашому дослідженні виявилась низькою. Можливим поясненням $\epsilon$ культурна невідповідність критеріїв психологічного благополуччя. В більшості досліджень показано низький рівень оптимізму українців та оцінки за принципом «погано - ще гірше». Доцільним, на нашу думку, буде з'ясування структури психологічного благополуччя іншими дослідницькими інструментами, а також здійснення психометричної перевірки інших версій Шкали психологічного благополуччя (зокрема адаптації С.В. Карсканової).

Висновки. Проведена психометрична перевірка Шкали психологічного благополуччя в модифікації Л. В. Жуковської, $\quad$ Є.Г. Трошихіної. Вона продемонструвала адаптивні психометричні властивості. Методика має прийнятний рівень надійності (за виключенням шкали самоприйняття) i внутрішньої узгодженості. Не була підтверджена оригінальна шестифакторна структура. Виявлено домінуючий фактор, який об'єднав параметри неблагополуччя особистості 3 різних сфер (самоприйняття, компетентності, життєвих цілей). Описувався негативний прояв взаємин, тобто актуалізованими були не позитивні, а негативні стосунки.

Позитивною стороною даної модифікації $\epsilon$ менший обсяг, що дає можливість зменшити часові витрати на дослідження. Однак відсутні тестові норми для чоловіків. Зафіксований низький рівень надійності шкали самоприйняття. 
Все вище зазначене змушує ставитися $з$ обережністю до застосування версії Шкали психологічного благополуччя в адаптації Л.В. Жуковської i Є.Г. Трошихіної у вітчизняній психодіагностичній i науково-дослідницькій практиці.

Подальші перспективи дослідження вбачаємо в емпіричній перевірці структури психологічного благополуччя в умовах української культури іншими дослідницькими методами.

\section{Jimepamypa:}

1. Ryff, C.D. (1989). Happiness is everything, or is it? Explorations on the meaning of psychological well-being. Journal Personal and Social Psychology, 57, 1069-1081.

2. Lawton, M.P. (1996). Quality of life and affect in later life. In C. Magai, S. H. McFadden (Eds.). Handbook of emotion, adult development and aging (pp. 327-348). San Diego, CA: Academic Press.

3. Личностный потенциал: структура и диагностика / Под ред. Д.А. Леонтьева. М.: Смысл, 2011. 678 с.

4. Карсканова С.В. Опитувальник «Шкали психологічного благополуччя» К. Ріфф: процес та результати адаптації. Практична психологія та соизіальна робота. 2011. №1. С. 1-10.

5. Березовська Л. Психологічне благополуччя та задоволеність життям: емпіричний ракурс. Вісник Національного університету оборони Украӥни. 2019. №3(53). С. 24-32.

6. Василець Н.М. Психологічне благополуччя особистості як чинник довіри громадян до працівників органів внутрішніх справ. Науковий вісник Львівського державного університету внутрішніх справ. 2016. №1. С. 12-20.

7. Харченко А.С., Гончарова Н.О. Особливості психологічного благополуччя студентів із різним типом спрямованості. Психологія і особистість. 2017. № 2 (12). С. 186-194.

8. Шевеленкова Т.Д., Фесенко П.П. Психологическое благополучие личности (обзор концепций и методика исследования). Психологическая диагностика. 2005. № 3. С. 95-129.

9. Гранкіна-Сазонова Н.В. Психологічне благополуччя та життєстійкість студентівпсихологів як важливі чинники освоєння професії. Psychological Journal. 2018. №7(17). C. 23-42.

10. Грузинова К.М. Особливості взаємозв'язку основних компонентів світогляду із психологічним благополуччям. Науковий вісник Харківського державного університету. 2020. Випуск 3. С. 14-22.

11. Данилюк І.В., Купрєєва О. Психологічне благополуччя в просторі самореалізації студентської молоді. Щастя та сучасне суспільство: збірник матеріалів міжнародної наукової конференції (Львів, 20-21 березня 2020 р.). Львів: СПОЛОМ, 2020. С. 63-66.

12. Діомідова Н.Ю., Шайхлісламов 3.Р., Лазоренко Т.М. Емоційний інтелект як фактор психологічного благополуччя майбутніх психологів. Вісник ХНПУ імені Г.С. Сковороди. Психологія. Випуск 62. 2020. С.108-122.

13. Жарікова С.Б. Гендерна специфіка взаємозв'язку психологічного благополуччя та диференційних типів рефлексії у студентів-першокурсників. Теорія $і$ практика сучасної психологї. 2019. №6. Том 1. С. 43-46.

14. Лепешинский Н.Н. Адаптация опросника «Шкалы психологического благополучия» К. Рифф. Психологический журнал. 2007. №3. С. 24-37.

15. Жуковская Л.В., Трошихина Е.Г. Шкала психологического благополучия К. Рифф. Психологический журнал. 2011. №2. Т.32. С. 82-93.

16. Осин Е.Н., Леонтьев Д.А. Апробация русско-язычных версий двух шкал экспрессоценки субъективного благополучия. Mam-ль III Всероссийского сочииологического конгресса. М.: Институт социологии РАН; Российское общество социологов, (CD), 2008. URL: https://www.hse.ru/pubs/share/direct/document/78753837 (дата звернення: 23.03.2013). 
17. Данильченко Т.В. Питальник «Суб'єктивне соціальне благополуччя»: методологічне обгрунтування і процедура розробки. East European Scientific Journal. 2015. № 3(4). C. 20-29.

18. Deci, E.L., Ryan, R.M. (1985). The General Causality Orientations Scale: SelfDetermination in Personality. Journal of Research in Personality, 19, 109-134.

19. Demir, M., Orthel, H., Andelin, K. (2013). Friendship and happiness. In S. A. David, I. Boniwell, A. C. Ayers (Eds.). The Oxford handbook of happiness (pp. 560-570). New York: Oxford University Press.

20. Huppert, F.A. (2009). A new approach to reducing disorder and improving well-being. Perspectives on Psychological Science, 4, 108-111.

21. Piliavin, J. (2009). Altruism and Helping: The Evolution of a Field. Social Psychology Quarterly, 72(3), 209-225.

\section{References:}

1. Ryff, C.D. (1989). Happiness is everything, or is it? Explorations on the meaning of psychological well-being. Journal Personal and Social Psychology, 57, 1069-1081.

2. Lawton, M.P. (1996). Quality of life and affect in later life. In C. Magai, S. H. McFadden (Eds.). Handbook of emotion, adult development and aging (pp. 327-348). San Diego, CA: Academic Press.

3. D.A. Leont'ev (Ed.). (2011). Lichnostnyj potencial: struktura i diagnostika [Personal potential: structure and diagnosis]. M.: Smysl. [in Russian]

4. Karskanova, S.V. (2011). Opytuvalnyk «Shkaly psykholohichnoho blahopoluchchia» K. Riff: protses ta rezultaty adaptatsii [C. Ryff's psychological well-being scale questionnaire: Adaptation process and results]. Praktychna psykholohiia ta sotsialna robota, 1, 1-10. [in Ukrainian]

5. Berezovsjka, L.I. (2019). Psykholohichne blahopoluchchia ta zadovolenist zhyttiam: empirychnyi rakurs [Psychological well-being and life satisfaction: An empirical perspective]. Visnyk Natsionalnoho universytetu oborony Ukrainy, 3(53), 24-32. [in Ukrainian]

6. Vasylets, N.M. (2016). Psykholohichne blahopoluchchia osobystosti yak chynnyk doviry hromadian do pratsivnykiv orhaniv vnutrishnikh sprav [Psychological well-being of the individual as a factor of public confidence in police officers]. Naukovyi visnyk Lvivskoho derzhavnoho universytetu vnutrishnikh sprav, 1, 12-20. [in Ukrainian]

7. Kharchenko, A.S., Goncharova, N.O. (2017). Osoblyvosti psykholohichnoho blahopoluchchia studentiv iz riznym typom spriamovanosti [Features of psychological well-being of students with different orientation types]. Psykholohiia i osobystist, 2(12), 186-194. [in Ukrainian]

8. Shevelenkova, T.D., Fesenko, P.P. (2005). Psihologicheskoe blagopoluchie lichnosti (obzor koncepcij i metodika issledovaniya) [Psychological well-being of the person (review of concepts and methods of research]. Psihologicheskaya diagnostika, 3, 95-129. [in Russian]

9. Grankina-Sazonova, N.V. (2018). Psykholohichne blahopoluchchia ta zhyttiestiikist studentiv-psykholohiv yak vazhlyvi chynnyky osvoiennia profesii [The psychology students' psychological well-being and hardiness]. Psychological Journal, 7(17), 23-42. [in Ukrainian]

10. Hruzynova, K.M. (2020). Osoblyvosti vzaiemozviazku osnovnykh komponentiv svitohliadu iz psykholohichnym blahopoluchchiam [Features of the relationship between the main components of the worldview and psychological well-being]. Naukovyi visnyk Khersonskoho derzhavnoho universytetu, 3, 14-22. [in Ukrainian]

11. Danyliuk, I.V., Kuprieieva, O. (2020). Psykholohichne blahopoluchchia v prostori samorealizatsii studentskoi molodi [Psychological well-being in the space of students' selfrealization]. Happiness And Contemporary Society: Conference Proceedings Volume (Lviv, March, 20-21, 2020) (pp. 63-66). Lviv: SPOLOM. [in Ukrainian]

12. Diomidova, N.Iu., Shaikhlislamov, Z.R., Lazorenko, T.M. (2020). Emotsiinyi intelekt yak faktor psykholohichnoho blahopoluchchia maibutnikh psykholohiv [Emotional intelligence as 
a factor in the psychological well-being of future psychologists]. Visnyk KhNPU imeni H.S. Skovorody. Psykholohiia, 62, 108-122. [in Ukrainian]

13. Zharikova, S.B. (2019). Henderna spetsyfika vzaiemozviazku psykholohichnoho blahopoluchchia ta dyferentsiinykh typiv refleksii u studentiv-pershokursnykiv [Gender specificity of the interrelation between psychological well-being and differential types of reflection in firstyear students]. Teoriia i praktyka suchasnoi psykholohii, 6(1), 43-46. [in Ukrainian]

14. Lepeshinskij, N.N. (2007). Adaptaciya oprosnika «Shkaly psihologicheskogo blagopoluchiya» K. Riff [Adaptation of the questionnaire "Scale of psychological well-being C. Ryff]. Psihologicheskij zhurnal, 3, 24-37. [in Russian]

15.Zhukovskaja, L.V., Troshihina, E.G. (2011). Shkala psihologicheskogo blagopoluchija K. Riff [Scale of psychological well-being of C. Ryff]. Psihologicheskij zhurnal, 2(32), 82-93. [in Russian]

16. Osin, E.N., Leontev, D.A. (2008). Aprobacija russkojazychnyh versij dvuh shkal jekspress-ocenki sub'ektivnogo blagopoluchiya [Approbation of Russian-language versions of two scales of an express assessment of subjective well-being]. In Mat-ly III Vserossijskogo sociologicheskogo kongressa (Moskva, 21-24 oktjabrja 2008 g.). [in Russian]. Retrieved from: URL:http://www.hse.ru/data/2010/03/15/1228959627/\%D0\%9E\%D181(2013):D0

17. Danilchenko, T.V. (2015). Pitalnik «Sub'ektivne sotsialne blagopoluchchia»: metodologichne obrruntuvannya i protsedura rozrobki [Questionnaire subjective social well-being: a methodological substantiation and working out procedure]. East European Scientific Journal, 3(4), 20-29. [in Ukrainian]

18. Deci, E.L., Ryan, R.M. (1985). The General Causality Orientations Scale: SelfDetermination in Personality. Journal of Research in Personality, 19, 109-134.

19. Demir, M., Orthel, H., Andelin, K. (2013). Friendship and happiness. In S. A. David, I. Boniwell, A. C. Ayers (Eds.). The Oxford handbook of happiness (pp. 560-570). New York: Oxford University Press.

20. Huppert, F.A. (2009). A new approach to reducing disorder and improving well-being. Perspectives on Psychological Science, 4, 108-111.

21. Piliavin, J. (2009). Altruism and Helping: The Evolution of a Field. Social Psychology Quarterly, 72(3), 209-225. 